\title{
Estimation of crop water requirement, effective rainfall and irrigation water requirement for vegetable crops using CROPWAT
}

\author{
R. GANESH BABU, G. RAVI BABU AND H.V. HEMA KUMAR
}

Received : 20.09.2014; Revised : 06.02.2015; Accepted : 19.02.2015

See end of the Paper for authors' affiliation

Correspondence to :

R. GANESH BABU

Department of Soil and Water

Engineering, College of

Agricultural Engineering, BAPATLA (A.P.) INDIA

\begin{abstract}
-ABSTRACT : Land and water resources are the basic needs of agriculture and for the economic development of any country. As water becomes increasing scare and increasing demand for irrigation water, everywhere, has now focused national attention and public interest on utilization of existing water supplies, integrated irrigation water conservation and management policy and practices. Accurate quantification of evapotranspiration is crucial for better management and allocation of water resources. It is important that the water requirements of crops are known at different management levels within the irrigated area to accomplish effective irrigation management. Estimation of the evapotranspiration and effective rainfall are extremely useful for operation planning and management issues. CROPWAT is a computer model, was used to estimate the reference evapotranspiration, effective rainfall, crop water requirement and irrigation water requirement for the Bapatla region in Andhra Pradesh state, India. Daily meteorological data including rainfall, maximum and minimum temperatures, relative humidity, wind speed and sunshine hours were collected for the period of 2009 to 2013 and used as input data for CROPWAT. Average peak monthly $\mathrm{ET}_{0}$ was observed to be $8.09 \mathrm{~mm} /$ day for the month of June and followed by the $7.55 \mathrm{~mm} /$ day for the month of May. Whereas average minimum $\mathrm{ET}_{0}$ were observed as 3.85 and $3.92 \mathrm{~mm} /$ day in the months of December and January, respectively. The average effective rainfall was estimated for the study area as $769.3 \mathrm{~mm}$ out of $1060.3 \mathrm{~mm}$ annual rainfall. The crop water requirement (ETc) and irrigation water requirement were estimated for vegetable crops during Rabi season in the study area (Bapatla) as $516.3 \mathrm{~mm}$ and $470.4 \mathrm{~mm}$, respectively.
\end{abstract}

- KEY WORDS : CROPWAT, Effective rainfall, $\mathrm{ET}_{\mathrm{O}}$, Crop water requirement, Bapatla region

- HOW TO CITE THIS PAPER : Babu, R. Ganesh, Babu, G. Ravi and Kumar, H.V. Hema (2015). Estimation of crop water requirement, effective rainfall and irrigation water requirement for vegetable crops using CROPWAT. Internat. J. Agric. Engg., 8(1) : 15-20. 